\title{
An Analytical Study of the Demand for Money in Saudi Arabia
}

\author{
Ahmed Y. Abdulkheir ${ }^{1}$ \\ ${ }^{1}$ Department of Economics \& Finance, Qassim University, Saudi Arabia \\ Correspondence: Ahmed Y. Abdulkheir, Department of Economics \& Finance, Qassim University, PO Box 5383, \\ Buraida, Al Qassim 51422, Saudi Arabia. E-mail: ahmedreihan@gmail.com
}

Received: February 14, 2013

Accepted: March 1, 2013

Online Published: March 18, 2013

doi:10.5539/ijef.v5n4p31

URL: http://dx.doi.org/10.5539/ijef.v5n4p31

\begin{abstract}
Empirical studies on the demand for money have been the object of great attention by economists due to its central role in conducting monetary policy by making it possible for monetary authorities to effect desired and predictable changes in targeted macroeconomic variables such as income, interest rate and prices by appropriate changes in monetary aggregates. The present study sought to investigate the cointegrating property of money demand in Saudi Arabia by using annual data for the period 1987-2009 and applying the vector error correction model (VECM) technique. Findings indicate clearly the existence of a long run cointegration relationship between the demand for money $\left(\mathrm{M}_{2}\right)$ and its explanatory variables, namely real GDP, the interest rate, the real exchange rate and the inflation rate. The error correction coefficient was found to be statistically significant and carries a minus sign as expected. The deviation of money demand from its long run value would be corrected in about a year and nine monthes.
\end{abstract}

Keywords: cointegration, money demand, error correction, M2 aggregate

\section{Introduction}

The demand for money function is a basic element in conducting monetary policy by making it possible for monetary authorities to effect desired and predictable changes in targeted macroeconomic variables such as income, interest rate and prices by appropriate changes in monetary aggregates. The demand function is an important catalyst in meeting the liquidity needs of economic agents (Handa, 2009). Because of its importance, the demand for money has long been the object of great attention by scholars and researchers.

Although, initially, research in this area was confined to the developed industrial countries, work on developing countries got underway since mid 1980s and has gained great momentum since then. The development of the vector error correction model (VECM) and related techniques of estimation has given an even greater impetus to the work on the demand for money almost worldwide.

The present study aims at estimating a theoretically sound model of the demand for money function for the Kingdom of Saudi Arabia.

It will investigate the cointegrating property of money demand in Saudi Arabia using the method of cointegration, of vector error correction model (VECM). We use the M2 monetary aggregate measured in real terms to represent money demand which is the dependent variable. The independent variables include real GDP as the scale variable along with the interest rate, the real exchange rate and the inflation rate. As is widely recognized in the literature, the demand for money is a very important element in the conduct of monetary policy. This fact may be of particular relevance to the case of Saudi Arabia where fiscal policy may not be readily manipulable to policy makers. For example government expenditures are closely linked to oil revenues and the related large government spending commitments which usually leave little room for maneuvers. On the other hand, taxation is not an important policy tool in the country . Since no previous studies have been carried out in this area for Saudi Arabia, this study probably gains added importance. The rest of this paper is organized as follows; Section 2 gives a literature review; Section 3 discusses the research model and data while section 4 explains the methodology and estimation pertaining to the cointegration tests. Section 5 discusses the vector error correction estimation results and section 6 concludes the paper.

\section{Literature Review}

A large body of literature exists with respect to empirical investigations of the demand for money. Although the 
study of the demand for money is appreciable on its own right, interest in the demand for money heightened as economists in some developed countries for instance set out to investigate whether financial reforms and innovations have adversely affected the stability of the demand for money. Thus the study by Drake and Chrystal (1994) for the UK found a stable money demand using divisia weighted monetary aggregates. Hafer and Jansen(1991) and Stock and Watson (1991) also found support for a long-run cointegrated money demand for the USA case. Miyao (1996) examines the case of Japan but cocludes that the data do not lend support to the stability of money demand in Japan. The study by Bahmani-Oskooee (2001) for the same country showed that M2 is not only cointegrated with the demand for money arguments, but that the relationship is stable.

Demand for money studies for developing countries sought in the main to explore the existence of a long run cointegration relationship for the money demand function as well as the stability of the function in many cases. Thus looking at Indian data for the period 1996Q2-2009Q2, Padhan (2011) found a long run cointegration relationship between money demand and its determinants using a number of monetary aggregates. Comparable results were reached by Achsani (2010) who studied the M2 demand for money for the case of Indonesia. A study of Bangladesh was carrid out by Hossain (2010). He concluded that a long run cointegration relationship in fact existed between broad money and the explanatory variables in the money demand function.

Some money demand studies were also done on African countries. For example a study of the Kenyan case by Adam (1992) confirmed the existence of a long run cointegrating relationship between a number of monetary aggregates and the arguments in money demand function. Likewise Oluwole and Olugbenga (2007) also confirmed the existence of an M2 money demand function for Nigeria which was also stable. The Egyptian money demand function was investigated 2 was unstable by Awad (2010). Using quarterly data for the period 1995-2007, he found that money demand for M2 was unstable. On the whole, it seems that a majority of the studies on money demand support the existence of a long run cointegration relationshipfor the money demand function and that it is largely stable.

\section{Model and Data}

The demand for money function has been represented by theorists in a number of ways. Nevertheless, most economists would postulate that the main arguments in the demand for money function comprise the scale variable which is customarily real income, although wealth and permanent income are better recommended if available, and opportunity cost variables. The usual general equasional representation of the demand for money function is:

$$
\frac{M}{P}=f(Y, R) \quad f_{Y}>o, f_{R}<0
$$

In this representation, $\mathrm{M}$ denotes nominal money supply, $\mathrm{R}$ denotes the interest rate. Money demand is assumed directly related to output but inversely related to the interest rate. However, as stated by Friedman (1987), the demand for money function can be expanded to incorporate several determinants such that we have

$$
(M / P)^{d}=f(y, r, E, S)
$$

Where $\mathrm{M}$ is the money stock, $\mathrm{P}$ is the general price level, $\mathrm{y}$ is real income, $\mathrm{r}$ is interest rate, $\mathrm{E}$ is the exchange rate and $\mathrm{S}$ is stock price. Equation (2) incorporates the exchange rate and stock price as additional explanatory variables for the money demand function. The moral of this is that foreign exchange and stocks are constituent parts of the asset portfolios held by investors. While money demand is expected apriori to be positively related to the exchange rate (Arango and Nadiri, 1981), the net effect of stock price could be either positive or negative from the theoretical stand point. Some economists argue that due to the weakness of financial markets in developing or emerging economies, real assets, rather than financial assets, may arguably be considered as alternatives to holding money (Sriram, 1999). Consequently we opt for the following specification for the money demand function:

$$
M_{2 t}=\beta_{0}+\beta_{1}(Y)_{t}+\beta_{2} r_{t}+\beta_{3} E_{t}+\beta_{4} \pi_{t}+e t
$$

Where $\mathrm{M}_{2} \mathrm{t}$ is the monetary aggregate in real terms, $\mathrm{Y}$ the real income, $\mathrm{r}$ the interest rate, $\mathrm{E}$ the real exchange rate, $\pi$ the inflation rate and $\mathrm{e}$ is an error term. According to Arango and Nadiri (1981) and Bahmani Oskooee and Pourheydarian (1990), an estimate of $\beta_{1}$ should have a positive sign, $\beta_{2}$ and $\beta_{3}$ could be negative or positive while $\beta_{4}$ is expected to be negative.

In order to estimate the model, annual data for the period from 1987 to 2007 will be used. Data for the monetary aggregate $\mathrm{M}_{2}$, the interest rate and real GDP were obtained from various issues of the annual reports of the Saudi 
Arabian Monetary Agency (SAMA) which is actually the central bank for the Kingdom of Saudi Arabia. The data for the real exchange rate and inflation were obtained from various issues of the international financial statistics published by the International Monetary fund.

\section{Methodology and Estimation}

We use the vector error correction model (VECM) integration technique (Johansen 1988) and Johansen and Joselius (1990)) to examine the long run cointegration relationship between the demand for money and its determinants. The application of integration requires that time series be tested for stationarity. A time series is said to be stationary if its mean and variance are invariant over time and the value of the covariance over the relevant time duration depends only on the gap or lag between the two time periods and not on the particular point in time in which the covariance is measured (Gujarati 2007). If the time series are stationary at level, then it would be possible to run a regression directly a'la the method of least squares. However, if the time series are not stationary at level, we take their first difference and then test their stationarity thereafter.

\subsection{Unit Root Tests}

To test for stationarity we use the Augmented Dickey-Fuller (ADF) and the Philips- Perron unit root testes. The model estimates are made both with a constant $(\mathrm{C})$ and with constant and trend $(\mathrm{C} \& \mathrm{~T})$. The results of the unit root tests are presented in tables 1 and 2 below.

Table 1 . Tests of time series stationarity at level ${ }^{1}$

\begin{tabular}{lllll}
\hline Variables & Dickey and Fuller $(\mathrm{C})$ & Phillip-Perron $(\mathrm{C} \& \mathrm{~T})$ & Phillip-Perron $(\mathrm{C})$ & Dickey and Fuller $(\mathrm{C} \& \mathrm{~T})$ \\
\hline M2 & $9.9571^{* * *}$ & $5.877359^{* * *}$ & $8.014959^{* * *}$ & $5.877359^{* * *}$ \\
INFLATION & -2.378662 & -2.838116 & -2.378662 & -2.831450 \\
GDP & 0.215271 & -1.583092 & 0.224082 & -1.645010 \\
INTEREST RATE & -1.774517 & -2.526306 & -1.605299 & $-4.844019^{* * *}$ \\
EXCHANGE RATE & -1.980556 & -0.966056 & -1.980556 & -0.966056 \\
\hline
\end{tabular}

Notes: *,*****: statistically significant at the 10 percent, 5 percent and, 1 percent level respectively. The time lag was chosen automatically through the Schwartz Info Criterion 1-

Table 2. Tests of time series stationarity at first difference

\begin{tabular}{lllll}
\hline Variables & Dickey and Fuller (C) & Phillip-Perron (C\&T) & Phillip-Perron (C) & Dickey and Fuller(C\&T ) \\
\hline M2 & -0.570769 & -1.984814 & -0.406534 & -1.907513 \\
INFLATION & $-5.963571^{* * *}$ & $-6.138676^{* * *}$ & $-5.976999^{* * *}$ & $-6.180467^{* * *}$ \\
GDP & $-4.123323^{* * *}$ & $-5.416393^{* * *}$ & $-4.455469^{* * *}$ & $-5.416393^{* * *}$ \\
INTEREST RATE & $-3.196739^{* *}$ & -2.963899 & $-3.025709^{* *}$ & -2.879203 \\
EXCHANGE RATE & $-2.774075^{*}$ & -3.091266 & $-2.724948^{*}$ & -2.708339 \\
\hline
\end{tabular}

Notes: *,**,**: statistically significant at the 10 percent, 5 percent and, 1 percent level respectively.

The results of the ADF and PP tests with constant (C) and with constant and trend (C\&T) indicate the presence of unit roots or non stationarity of all variables at level. However all the variables show stationarity for their first difference mostly at the 10 percent level of significance except for the M2 variable which has been found stationary at level. Since we have a mixture of variables in the model some of which are integrated of order one, I (1) and others are integrated of zero order, I (0), then it is possible to estimate the longrun relationship between them using the cointegration technique. (Enders 2008; Gujarati, 2007). Thus we move on next to run cointegration tests for the time series of the variables to find the extent of the long run relationship between the demand for money and its explanatory variables. If indeed a cointegration relationship exists, then the vector error correction can be used to identify the nature of the relation between the model variables in the short and long runs.

\subsection{Results of Cointegration Tests}

We proceed now to run the cointegration test of Johansen (1988) and Johansen- Juselius (1990) based on the maximum likelihood estimation procedure. In this test we look for the number of cointegration vectors present in the series. In this $\mathrm{n}$ variable case, the presence of at least one cointegrating vector is sufficient to establish the existence of cointegration among the variables. The twin statistics of trace and maximum eigenvalue are used to 
determine the number of cointegration vectors.

The results are reported in table 3 below.

Table 3. Cointgration test between money demand and its explanatory variables

Included observations: 24 after adjusting endpoints

Trend assumption: Linear deterministic trend

Series: M2 INFLATION GDP INTERESTRATE EXCHANGERATE

Lags interval (in first differences): 1 to 1

Unrestricted Cointegration Rank Test

\begin{tabular}{lllll}
\hline 1 Percent & 5 Percent & Trace & & Hypothesized \\
\hline Critical Value & Critical Value & Statistic & Eigenvalue & No. of CE(s) \\
\hline 76.07 & 68.52 & 122.6611 & 0.942545 & None ** \\
54.46 & 47.21 & 54.09896 & 0.771935 & At most $1^{*}$ \\
35.65 & 29.68 & 18.62395 & 0.395894 & At most 2 \\
20.04 & 15.41 & 6.527812 & 0.182033 & At most 3 \\
6.65 & 3.76 & 1.705408 & 0.068593 & At most 4 \\
\hline
\end{tabular}

$*(* *)$ denotes rejection of the hypothesis at the $5 \%(1 \%)$ level

Trace test indicates 2 cointegrating equation(s) at the $5 \%$ level

Trace test indicates 1 cointegrating equation(s) at the $1 \%$ level

\begin{tabular}{lllll}
\hline 1 Percent & 5 Percent & Max-Eigen & & Hypothesized \\
\hline Critical Value & Critical Value & Statistic & Eigenvalue & No. of CE(s) \\
\hline 38.77 & 33.46 & 68.56216 & 0.942545 & None ** \\
32.24 & 27.07 & 35.47501 & 0.771935 & At most 1 ** \\
25.52 & 20.97 & 12.09614 & 0.395894 & At most 2 \\
18.63 & 14.07 & 4.822404 & 0.182033 & At most 3 \\
6.65 & 3.76 & 1.705408 & 0.068593 & At most 4 \\
\hline
\end{tabular}

$*(* *)$ denotes rejection of the hypothesis at the $5 \%(1 \%)$ level

Max-eigenvalue test indicates 2 cointegrating equation(s) at both $5 \%$ and $1 \%$ levels

The test for cointegration between money demand and its explanatory variables, namely real GDP, the interest rate, exchange rate and inflation in the kingdom of Saudi Arabia and for the period 1987-2009 shows that cointegration in fact exists between the variables of the model with two cointegration vectors available at the 5 percent level of significance based on the trace test and one cointegration vector at the 1 percent level of significance. As for the maximum eigenvalue test, it indicates the existence of two cointegration vectors at both the 5 percent and 1 percent level of significance. Consequently it is possible to estimate the equilibrium long run relationship between money demand and its explanatory variables and employ vector error correction in estimating short run relationship.

\subsection{Granger Causality}

Having established cointegration between the variables, causality between the variables is tested for using the Granger (1987) causality test. Engel-Granger show that if a cointegration relation exists between the model variables, this implies that they are also causally related unidirectionally or bidirectionally. Different lags will be used to determine the direction of causality to and from money demand since some of the variables may not affect money demand instantaneously but their effect may show after a certain amount of time. The results of the causality tests are shown in tables (4), ( 5 ) and ( 6 ) below.

Table 4. One lag causality test results

\begin{tabular}{lll}
\hline Causality direction & F-Statistic & Probability \\
\hline M2 $\rightarrow$ INFLATION & 5.46423 & 0.02738 \\
GDP $\rightarrow$ M2 & 6.73392 & 0.01535 \\
M2 $\rightarrow$ Interest rate & 4.43393 & 0.04687 \\
Exchange rate $\rightarrow$ Inflation & 4.63111 & 0.04086 \\
Inflation $\rightarrow$ Exchange rate & 8.79088 & 0.00641 \\
GDP $\rightarrow$ Interest rate & 4.77001 & 0.03991 \\
\hline
\end{tabular}


Table 5. Two lags causality test results

\begin{tabular}{lcc}
\hline Causality direction & F-Statistic & Probability \\
\hline $\mathrm{M} 2 \rightarrow$ Interest rate & 5.09674 & 0.01690 \\
$\mathrm{GDP} \rightarrow$ Interest rate & 5.09723 & 0.01690 \\
Exchange rate $\rightarrow$ GDP & 3.65611 & 0.04181 \\
Interest rate $\rightarrow$ Exchange rate & 4.92123 & 0.01896 \\
\hline
\end{tabular}

Table 6. Three lags causality test results

\begin{tabular}{lll}
\hline Causality direction & F-Statistic & Probability \\
\hline Interest rate $\rightarrow$ M2 & 3.47529 & 0.04089 \\
\hline
\end{tabular}

The results show that real. GDP affects the demand for money and the interest rate with a lag of one period (i. e one year), whereas money demand affects inflation and interest rate in the following year but the effect on the interest rate is carried over to the third year before a counter-effect ensues in the fourth year from the interest rate to money demand. There is also a unidirectional effect from the exchange rate to real GDP. There is also a bidirectional effect between inflation and the real exchange rate with a one period lag.

\section{Vector Error Correction Model (VECM) Results}

On estimating the research model using vector error correction with first difference and a log of two periods, the researcher obtained the results for the long run and short run relationships between the demand for money and its explanatory variables as indicated in the following equation: (These results are also shown in table (7) portrayed at the end of this section)

$\mathrm{D}(\mathrm{M} 2)=-0.53 *(\mathrm{M} 2(-1)+16.33 *$ INFLATION $(-1)+0.096 * \mathrm{GDP}(-1)+30.34 *$ INTERESTRATE(-1) $1.72 *$ EXCHANGERATE(-1) -396.14$)+2.11 * \mathrm{D}(\mathrm{M} 2(-1))+1.92 * \mathrm{D}(\mathrm{M} 2(-2))+4.26 * \mathrm{D}($ INFLATION(-1)) $1.49 * \mathrm{D}($ INFLATION(-2) $)+0.144 * \mathrm{D}(\mathrm{GDP}(-1))+0.04 * \mathrm{D}(\mathrm{GDP}(-2))+1.436374307 * \mathrm{D}(\mathrm{INTERESTRATE}(-1))+$ $23.06 * \mathrm{D}($ INTERESTRATE $(-2))+0.65 * \mathrm{D}$ (EXCHANGERATE $(-1))+0.83 * \mathrm{D}$ (EXCHANGERATE $(-2))-86.59$

In analyzing the results, we first point out that the error correction coefficient was about 0.53 , with a negative sign and statistically significant. This means that the disparity between the value of money demand in period ( $t-1)$ and its long run equilibrium value is corrected by as much as 53 percent. This means that the deviation of money demand from long run value is corrected in about a year and nine monthes. Further, there is a statistically significant long run relationship between money demand and each of the interest rate, inflation rate and the exchange rate but the relation between money demand and real GDP is not significant statistically.

There is also a statistically significant long run relation between the inflation rate and money demand such that a rise of inflation by 1 percent results in an increase in money demand by 16.33 percent, whereas in the short run results show a positive and significant relation between money demand and inflation in the following year only such that a rise in inflation by 1 percent increases money demand in the following year by 4.26 percent. There is also no statistically significant long run relation between GDP and money demand in the kingdom of Saudi Arabia. As for the short run, results indicate that there is a statistically significant relationship between the two variables in the following year only such that an increase in GDP by 1 percent increases money demand in the following year by 0.14 percent. The interest rate is apparently a very important determinant of Saudi money demand both in the short and long runs with an increase in interest rate by 1 percent in the long run resulting in a rise of 30.34 percent in money demand. In the short run an increase of 1 percent in the interest rate leads to an increase of 23.06 in money demand in two year's time.

As for the relation between the real exchange rate and the money demand function, it showed a negative long run relationship in which a rise in the real exchange rate (a depreciation of the riyal) by 1 percent reduces the demand for money in the long run by $17 \%$ But the short run in contrast shows a positive statistically significant relation between the real exchange rate and money demand where an increase by 1 percent in real exchange rate in the short run leads to an increase in money demand by 0.83 percent after two years.

There is also a statistically significant relation between money demand in any single year and the following couple of years such that an increase in money demand by 1 percent in a certain year increases money demand in the following two years by 2.11 and 1.92 percent respectively.

Lastly, the coefficient of determination is 97 percent which means that the explanatory variables (real GDP, the 
interest rate, the real exchange rate, the inflation rate) account for 97 percent of the variation in money demand the remainder ( 3 percent) is due to factors not included in the model.

Table 7. Results of the vector error correction model (VECM)

\begin{tabular}{|c|c|c|c|c|c|}
\hline \multicolumn{6}{|c|}{$\begin{array}{l}\text { Vector Error Correction Estimates } \\
\text { Sample(adjusted): } 19872009 \\
\text { Included observations: } 23 \text { after adjusting endpoints } \\
\text { Standard errors in ( ) \& t-statistics in [ ] }\end{array}$} \\
\hline & & & & CointEq1 & Cointegrating Eq: \\
\hline & & & & 1.000000 & M2(-1) \\
\hline & & & & 16.33043 & INFLATION(-1) \\
\hline & & & & $(1.86210)$ & \\
\hline & & & & [ 8.76988] & \\
\hline & & & & 0.096374 & $\operatorname{GDP}(-1)$ \\
\hline & & & & $(0.06080)$ & \\
\hline & & & & {$[1.58520]$} & \\
\hline & & & & 30.34201 & INTERESTRATE(-1) \\
\hline & & & & $(3.70493)$ & \\
\hline & & & & [ 8.18964] & \\
\hline & & & & -1.720920 & EXCHANGERATE(-1) \\
\hline & & & & $(0.57819)$ & \\
\hline & & & & {$[-2.97638]$} & \\
\hline & & & & -396.1432 & $\mathrm{C}$ \\
\hline D(EXCHANGERATE) & D(INTERESTRATE) & $\mathrm{D}(\mathrm{GDP})$ & D(INFLATION) & $\mathrm{D}(\mathrm{M} 2)$ & Error Correction: \\
\hline 0.100636 & -0.013744 & -3.876082 & -0.016614 & -0.534779 & CointEq1 \\
\hline$(0.05160)$ & $(0.01160)$ & $(0.77736)$ & $(0.02401)$ & $(0.10507)$ & \\
\hline$[1.95041]$ & {$[-1.18430]$} & {$[-4.98618]$} & {$[-0.69210]$} & {$[-5.08965]$} & \\
\hline-0.342162 & 0.057398 & 14.97498 & 0.068830 & 2.117969 & $\mathrm{D}(\mathrm{M} 2(-1))$ \\
\hline$(0.18433)$ & $(0.04146)$ & $(2.77717)$ & $(0.08576)$ & $(0.37537)$ & \\
\hline$[-1.85620]$ & [ 1.38445$]$ & [ 5.39218] & {$[0.80259]$} & {$[5.64230]$} & \\
\hline-0.228176 & 0.033417 & 9.051918 & 0.076852 & 1.921435 & $\mathrm{D}(\mathrm{M} 2(-2))$ \\
\hline$(0.16439)$ & $(0.03697)$ & $(2.47664)$ & $(0.07648)$ & $(0.33475)$ & \\
\hline$[-1.38804]$ & [ 0.90384$]$ & [3.65491] & [ 1.00487$]$ & {$[5.73985]$} & \\
\hline-1.907760 & -0.133830 & 23.39226 & -0.332957 & 4.267811 & D(INFLATION(-1)) \\
\hline$(0.91700)$ & $(0.20624)$ & $(13.8155)$ & $(0.42663)$ & $(1.86736)$ & \\
\hline$[-2.08043]$ & {$[-0.64889]$} & [ 1.69319$]$ & {$[-0.78044]$} & [ 2.28548] & \\
\hline-0.250414 & -0.160072 & 3.132356 & -0.014603 & -1.491797 & D(INFLATION(-2)) \\
\hline$(0.71322)$ & $(0.16041)$ & $(10.7454)$ & $(0.33182)$ & $(1.45239)$ & \\
\hline$[-0.35110]$ & {$[-0.99788]$} & [0.29151] & {$[-0.04401]$} & {$[-1.02713]$} & \\
\hline 0.006036 & 0.003051 & 0.424753 & -0.011651 & 0.144513 & $\mathrm{D}(\mathrm{GDP}(-1))$ \\
\hline$(0.02711)$ & $(0.00610)$ & $(0.40837)$ & $(0.01261)$ & $(0.05520)$ & \\
\hline$[0.22270]$ & {$[0.50052]$} & [ 1.04011] & {$[-0.92387]$} & [ 2.61812] & \\
\hline-0.002952 & -0.007394 & -0.803459 & -0.001444 & 0.040613 & $\mathrm{D}(\mathrm{GDP}(-2))$ \\
\hline$(0.03186)$ & $(0.00717)$ & $(0.48004)$ & $(0.01482)$ & $(0.06488)$ & \\
\hline$[-0.09264]$ & {$[-1.03175]$} & {$[-1.67373]$} & {$[-0.09744]$} & {$[0.62593]$} & \\
\hline-0.649116 & 0.456498 & 27.92451 & 0.715490 & 1.436374 & D(INTERESTRATE(-1)) \\
\hline$(1.08392)$ & $(0.24379)$ & $(16.3303)$ & $(0.50428)$ & $(2.20727)$ & \\
\hline$[-0.59886]$ & [ 1.87253$]$ & [ 1.70999] & [ 1.41882$]$ & {$[0.65075]$} & \\
\hline-1.888574 & 0.196935 & 148.1269 & 0.797685 & 23.06340 & D(INTERESTRATE(-2)) \\
\hline$(2.19241)$ & $(0.49310)$ & $(33.0306)$ & $(1.02000)$ & $(4.46456)$ & \\
\hline$[-0.86142]$ & [ 0.39938$]$ & [ 4.48453] & {$[0.78205]$} & [ 5.16588] & \\
\hline 0.159994 & 0.057765 & 7.791149 & -0.031360 & 0.656073 & D(EXCHANGERATE(-1)) \\
\hline$(0.16938)$ & $(0.03810)$ & $(2.55185)$ & $(0.07880)$ & $(0.34492)$ & \\
\hline [ 0.94459$]$ & [ 1.51632$]$ & [3.05314] & {$[-0.39796]$} & [ 1.90211$]$ & \\
\hline-0.197513 & -0.027858 & 4.623349 & 0.011095 & 0.831701 & D(EXCHANGERATE(-2)) \\
\hline$(0.14029)$ & $(0.03155)$ & $(2.11356)$ & $(0.06527)$ & $(0.28568)$ & \\
\hline
\end{tabular}




\begin{tabular}{llllll}
\hline$[-1.40791]$ & {$[-0.88290]$} & {$[2.18747]$} & {$[0.16999]$} & {$[2.91132]$} & \\
15.26136 & -2.649367 & -611.4255 & -2.921066 & -86.59473 & $\mathrm{C}$ \\
$(8.94207)$ & $(2.01117)$ & $(134.720)$ & $(4.16021)$ & $(18.2094)$ & \\
{$[1.70669]$} & {$[-1.31732]$} & {$[-4.53848]$} & {$[-0.70214]$} & {$[-4.75550]$} & \\
0.729577 & 0.593896 & 0.813194 & 0.530179 & $\mathbf{0 . 9 7 0 8 0 8}$ & R-squared \\
0.459153 & 0.187791 & 0.626387 & 0.060359 & $\mathbf{0 . 9 4 1 6 1 6}$ & Adj. R-squared \\
301.3430 & 15.24349 & 68399.38 & 65.22515 & 1249.614 & Sum sq. resids \\
5.234006 & 1.177188 & 78.85509 & 2.435069 & 10.65839 & S.E. equation \\
2.697906 & 1.353134 & 1.128472 & 33.25603 & F-statistic \\
-62.22227 & 1.462421 & -124.6083 & -44.62262 & -78.57919 & Log likelihood \\
6.454110 & -27.90516 & 11.87898 & 4.923706 & 7.876451 & Akaike AIC \\
7.046542 & 3.470014 & 12.47141 & 5.516138 & 8.468883 & Schwarz SC \\
-2.840000 & 4.062446 & 47.26522 & 0.359565 & 38.19130 & Mean dependent \\
7.117003 & -0.298652 & 129.0086 & 2.512061 & 44.11082 & S.D. dependent \\
\hline & 1.306207 & & 39979957 & Determinant Residual Covariance \\
& & -322.0607 & Log Likelihood \\
& & -364.4727 & Log Likelihood (d.f. adjusted) \\
\hline
\end{tabular}

\section{Conclusion}

This study sought to investigate the cointegrating property of money demand in Saudi Arabia using annual data for the period 1987-2009 and the vector error correction model (VECM) technique. The results of the study indicate clearly that a long run cointegration relation in fact exists between the demand for money $\left(\mathrm{M}_{2}\right)$ and its explanatory variables, namely real GDP, the interest rate, the real exchange rate and the inflation rate. By using the (VECM) approach to estimate the long run relationship between money demand and its arguments, the long run relationships as well as the short run dynamics of the model were uncovered with the error correction coefficient found to be statistically significant and with a negative sign as expected. Granger causality tests show among other things that money demand affects inflation and interest rate in the following year but the effect on the interest rate is carried over to third year but a counter effect ensues in the fourth year from interest to money demand. There is also a bidirectional shown between inflation and the exchange rate with a lag of one period, a result which indicates that the real exchange rate has been one the sources of inflation in Saudi Arabia .

\section{References}

Achsani, N. A. (2010). Stability of Money Demand in an Emerging Market Economy: An Error Correction and ARDL Model for Indonesia. Research Journal of International Studies, 13, 54-62.

Adam, C. S. (1992). On the dynamic specification of money demand in Kenya. Journal of African Economies, 1(2), 233-270.

Arango, S., \& Nadiri, M. I. (1981). Demand for money in open economy. Journal of Monetary Economics, 7 , 69-83. http://dx.doi.org/10.1016/0304-3932(81)90052-0

Awad, I. L. (2010). Measuring the stability of the demand for money function in Egypt. Banks and Bank Systems, 5(1), 71-75.

Bahmani-Oskooee, M. (2001). How stable is M2 money demand function in Japan? Japan and the World Economy, 13, 455-461. http://dx.doi.org/10.1016/S0922-1425(01)00064-0

Bahmani-Oskooee, M., \& Pourheydarian, M. (1990). Exchange rate sensitivity of demand for money and effectiveness of fiscal and monetary policies. Applied Economics, 22, 917-925. http://dx.doi.org/10.1080/00036849000000029

Drake, L., \& Chrystal, K. A. (1994). Company-sector money demand: new evidence on the existence of a stable long-run relationship for the UK. Journal of Money, Credit and Banking, 26(3), 479-494. http://dx.doi.org/10.2307/2078013

Enders, W. (2008). Applied Econometric Time Series. John Wiely \& sons, Inc.

Engle, R. F., \& Granger, C. W. J. (1987). Co- Integration and Error CorA rection: Representation, Estimation, and Testing. Econometrica, 55(2), 251-76. http://dx.doi.org/10.2307/1913236 
Friedman, M. (1987). The quantity theory of money. In J Eatwell, M Milgate and P Newman (Eds.), The new pal grave: A Dictionary of Economics (Vol. 4). London: McMillian Press.

Gugariti, D. (2007). Basic Econometrics. New Delhi: McGraw-Hill Publishing Company Limited.

Hafer, R. W., \& Jansen, D. W. (1991). The demand for money in the United States : Evidence from cointegration test. Journal of Money, Credit, and Banking, 23(2), 155-168. http://dx.doi.org/10.2307/1992774

Handa, J. (2009). Monetary Economics. New York: Routledge Taylor \& Francis Group.

Hossain, A. A. (2010). Monetary targeting for price stability in Bangladesh: how stable is its money demand function and the linkage between money supply growth and inflation. Journal of Asian Economics, 21, 564-578. http://dx.doi.org/10.1016/j.asieco.2010.07.003

Johansen, S. (1988). Statistical analysis of co integrating vectors. Journal of Economic Dynamics and Control, 12, 321-354. http://dx.doi.org/10.1016/0165-1889(88)90041-3

Johansen, S., \& Juselius, K. (1990). Maximum likelihood and inferences on cointegration- with applications to the demand for money. Oxford Bulletin of Economics and Statistics, 52, 169-210. http://dx.doi.org/10.1111/j.1468-0084.1990.mp52002003.x

Miyao, R. (1996). Does a cointegrating demand relation really exist in the United States? Journal of Money, Credit, and Banking, 28(3), 365-380. http://dx.doi.org/10.2307/2077980

Oluwole, O., \& Onafowora, O. A. (2007). M2 targeting, money demand, and real GDP growth in Nigeria: do rules apply? Journal of Business and Public Affairs, 1(2), 1-20.

Padhan, P. C. (2011). Stability of demand for money in India: Evidence from monetary and Liquidity Aggregates. International Journal of Economics and Finance, 3(1), 271-282.

Sriram, S. S. (1999). Survey of literature on demand for money: theoretical and empirical work with special reference to error- correction models. IMF Working Paper 99/64. Washington, International Monetary Fund.

Stock, J. H., \& Watson, M. W. (1993). A simple estimator of cointegrating vectors in higher order integrated systems. Econometrica, 61(4), 783-820. http://dx.doi.org/10.2307/2951763 